\title{
Crenças Religiosas e Evolução: Um Modelo para o Diálogo em Aula
}

\section{Religious Beliefs and Evolution: A Model for the Dialogue in Classroom}

\author{
Pedro Teixeira ${ }^{a}$; Ralph Levinson ${ }^{b}$ \\ a Departamento de Educação, Pontifícia Universidade Católica do Rio de Janeiro, Rio de Janeiro, Brasil - \\ teixeirapp86@gmail.com \\ b Institute of Education, University College London, Londres, Reino Unido -r.levinson@ucl.ac.uk
}

\section{Palavras-chave:}

Ensino de biologia.

Ensino de evolução.

Crenças religiosas.

Criacionismo.
Resumo: A teoria evolutiva é defendida como eixo organizador do ensino de biologia, porém há várias dificuldades para tal, incluindo conflitos com determinadas orientações religiosas que realizam uma leitura literal da Bíblia, como o pentecostalismo. Nesta pesquisa, procuramos compreender de que maneira o ensino da teoria evolutiva é desenvolvido em contextos de grande presença de estudantes pentecostais. Para isso, investigamos duas escolas com grande número de estudantes pentecostais através de observações, entrevistas e questionários. Os resultados mostram que quando os professores discutem evolução, eles desvalorizam ou mostram receio em relação às ideias religiosas dos alunos ou introduzem suas crenças pessoais. Propomos um modelo de diálogo, baseado na ideia de discurso de Habermas e de espaço de busca de France, no qual bases comuns podem ser encontradas a fim de promover a compreensão da evolução sem o intuito de converter pontos de vista diferentes. Mostramos as possibilidades do modelo aplicadas aos nossos dados e apontamos para desenvolvimentos futuros.

\section{Keywords:}

Biology teaching.

Evolution teaching.

Religious beliefs.

Creationism.

\begin{abstract}
Evolutionary theory is defended as an organizing axis for biology teaching, but there are difficulties to do so, including conflicts with some religious orientations that perform literal readings of the Bible, such as Pentecostalism. In this research, we sought to understand how the teaching of evolution is developed in contexts of great presence of Pentecostal students. For this purpose, we have investigated two schools with large numbers of Pentecostal students by means of observation, interviews and questionnaires. The results show that when teachers discuss evolution, they dismiss or show fear of students' religious ideas or introduce their own personal beliefs. We propose a model of dialogue, based on the Habermas's idea of discourse and France's idea of search space, where common ground can be found to promote the understanding of evolution without the intention of converting different views. We show the possibilities for the model applied to our data and point to future developments.
\end{abstract}




\section{Introdução}

A teoria evolutiva é considerada um dos principais eixos da biologia enquanto disciplina acadêmica (DOBZHANSKI, 1973; MAYR, 1982). O desenvolvimento dos estudos em genética e em evolução, através da teoria sintética da evolução, forneceram bases para a unificação de diferentes áreas de conhecimento - como zoologia, botânica e ecologia, por exemplo - sob o paradigma mais amplo da biologia. Documentos curriculares (BRASIL, 2006) e pesquisadores em ensino de ciências (SANTOS, 2002; SANDERS; NGXOLA, 2009) apontam a importância da teoria evolutiva também para a disciplina escolar biologia, uma vez que através dela são construídas as explicações para a diversidade biológica, bem como para a classificação e identificação dos seres vivos. Esta concepção pode ser encontrada nos Parâmetros Curriculares Nacionais do Ensino Médio (BRASIL, 1998) e fica ainda mais explícita nas Orientações Curriculares para o Ensino Médio (OCEM):

Um tema de importância central no ensino de Biologia é a origem e evolução da vida. Conceitos relativos a esse assunto são tão importantes que devem compor não apenas um bloco de conteúdos tratados em algumas aulas, mas constituir uma linha orientadora das discussões de todos os outros temas. (...) A presença do tema origem e evolução da vida ao longo de diferentes conteúdos não representa a diluição do tema evolução, mas sim a sua articulação com outros assuntos, como elemento central e unificador no estudo da biologia (BRASIL, 2006, p.22).

No entanto, pesquisas mostram diversas dificuldades relacionadas ao ensino e à aprendizagem da teoria evolutiva (SANTOS, 2002), dentre as quais se destaca o relacionamento com crenças religiosas que realizam uma leitura literal da Bíblia (EL-HANI; SEPULVEDA, 2009; SMITH, 2010). Ainda que os movimentos anti-evolucionistas e fundamentalistas tenham surgido e sejam mais presentes nos EUA, nas últimas décadas essas iniciativas se espalharam para outros países (NUMBERS, 2006). No Brasil, as denominações evangélicas pentecostais têm demonstrado crescente resistência a esse tema (DORVILLÉ; SELLES, 2009), inclusive por meio da publicação de livros e DVDs (MALAFAIA, 2009), marcando posicionamento contrário à teoria evolutiva, bem como com projetos de lei para a introdução do ensino de criacionismo em instituições educativas públicas e privadas (BRASIL, 2014). Um destes projetos de lei, de autoria do deputado federal pastor Marco Feliciano, foi amplamente criticado por parte da imprensa (TUFFANI, 2014), de sociedades científicas (ABRAPEC; SBENBIO, 2014; SBPC, 2014), com relação aos erros conceituais contidos no projeto e o caráter não científico do criacionismo.

O pentecostalismo é um segmento do cristianismo surgido no final do século XIX nos EUA (MENDONÇA, 2006). De maneira geral, caracteriza-se pela ênfase nos dons do Espírito Santo (em especial, o dom de cura e o de falar em línguas ${ }^{1}$ ), não realiza estudos

\footnotetext{
${ }^{1}$ De acordo com Mariano (1999), o dom de falar línguas estranhas, que desde o início do pentecostalismo constitui uma de suas principais marcas distintivas, remete ao episódio bíblico de Pentecostes, relatado em Atos 
teológicos aprofundados e rejeita o que é mundano ${ }^{2}$ e não supostamente associado a Deus (MARIANO, 1999). No Brasil, é comum dividir sua história em três ondas (FRESTON, 1993; MARIANO, 1999). A primeira, nos primeiros decênios do século XX, é marcada pela vinda de missionários estrangeiros que fundaram as igrejas pioneiras (Congregação Cristã no Brasil, 1910, e Assembleia de Deus, 1911). A segunda onda ocorreu durante as décadas de 1950 e 1960 e foi marcada pelo surgimento de novas igrejas (Evangelho Quadrangular, 1953, Brasil para Cristo, 1955, Deus é Amor, 1962) sem que houvesse, no entanto, mudanças teológicas e doutrinárias significativas em comparação com a primeira. A terceira onda se inicia na década de 1970 e se estende até os dias de hoje. Esta etapa é marcada pelo forte crescimento de fieis e por mudanças teológicas que fazem com que diversos autores se refiram a esse momento como neopentecostalismo. O crescimento evangélico pentecostal e neopentecostal se deu, principalmente, nas periferias de grandes centros urbanos, notoriamente no Rio de Janeiro e em São Paulo (ALMEIDA, 2009), onde surgiram grandes igrejas do cenário atual como a Igreja de Nova Vida, a Igreja Universal do Reino de Deus e a Igreja Internacional da Graça de Deus.

Ainda que determinadas interpretações dos textos bíblicos, numa perspectiva pentecostal, possam se mostrar como obstáculos para a compreensão da teoria evolutiva, é importante ressaltar a posição que diferentes autores têm defendido no sentido de respeitar a religiosidade dos estudantes e de defender que o objetivo do ensino de ciências deve ser o entendimento e não uma mudança de crença por parte dos alunos (COBERN, 1994³; 2000; SMITH; SIEGEL, 2004; REISS, 2008; 2009). Assim, o ensino da teoria da evolução deve estar orientado para a sua compreensão enquanto teoria científica, construída a partir de evidências empíricas e múltiplos estudos, sem que isto seja imposto como uma verdade absoluta ao estudante cujas crenças, porventura, possam entrar em choque com a visão da ciência.

O presente trabalho tem como foco o ensino e a aprendizagem da teoria evolutiva em escolas estaduais do Rio de Janeiro com grande presença de alunos evangélicos pentecostais. O objetivo principal foi identificar e analisar as relações, os conflitos e as aproximações entre a evolução biológica e o criacionismo em aulas de biologia em contextos de forte presença pentecostal e neopentecostal. Os resultados aqui apresentados e discutidos são parte da pesquisa de doutorado do primeiro autor. A partir de France (2011) e Habermas (1984; 1989) foi construído um modelo de "espaço de busca", baseado na ideia habermasiana de discurso,

dos Apóstolos, capítulo 2, em que o Espírito Santo, no quinquagésimo dia da ressurreição de Cristo, teria se manifestados aos apóstolos por meio de línguas de fogo.

${ }^{2} \mathrm{O}$ termo mundano se refere a práticas e elementos culturais que fogem à doutrina da religiosa pentecostal, como determinados estilos musicais, vestuário, uso de álcool, cigarro e outras substâncias.

${ }^{3}$ Cobern (1994) usa o termo "understanding" aqui traduzido em versão livre como "entender". 
estabelecido em sala de aula entre educandos e professor/a, a fim de encontrar bases acordadas para proporcionar um diálogo com intuito de promover o entendimento da teoria evolutiva. Para cada caso aqui discutido aplicamos o modelo e debatemos suas possibilidades de utilização e limitações com a literatura da área, tendo em vista os objetivos de uma proposta de ensino de biologia que respeite a diversidade religiosa presente na escola e que atue no sentido de promover o entendimento da teoria evolutiva.

\section{Metodologia}

A coleta de dados foi realizada em duas escolas da rede estadual do Rio de Janeiro, em turmas de primeiro ano do ensino médio regular, etapa em que os conteúdos de evolução e origem da vida devem ser ensinados, de acordo com o Currículo Mínimo prescrito pela Secretaria Estadual de Educação (SEEDUC, 2012). Uma das escolas, Colégio Guarani ${ }^{4}$, está localizada no bairro da Gávea, uma das regiões mais valorizadas da Zona Sul da capital fluminense, atendendo majoritariamente a estudantes de camadas populares moradores de comunidades próximas e de alguns bairros da Zona Oeste da cidade. A segunda escola, Colégio Passaredo, está situada na cidade de Nilópolis, na Região Metropolitana do Rio de Janeiro, e também recebe educandos de camadas populares moradores de comunidades. A escolha por essas duas escolas se deu em função da distribuição dos evangélicos pentecostais de acordo com os dados do Censo Demográfico de 2010 (IBGE, 2012). A Zonal Sul do Rio de Janeiro, incluindo as favelas ali presentes, possuem percentuais pequenos de evangélicos pentecostais em comparação com as cidades da periferia da Região Metropolitana, como Nilópolis. Assim, o estudo de duas escolas localizadas em contextos de diferentes perfis religiosos nos permitiria encontrar aproximações e distanciamentos relacionados ou não a questões religiosas.

Foram realizadas observações das aulas de biologia, das salas de professores e de outros ambientes das duas escolas ao longo de nove meses (de fevereiro a outubro de 2014). Além das observações, foram realizadas entrevistas com sete professores de biologia (quatro do Colégio Guarani e três do Colégio Passaredo) e vinte estudantes (dez de cada escola) e um questionário foi aplicado a todas as turmas de primeiro ano de ambas as escolas. A seleção dos estudantes para as entrevistas não foi randômica, mas sim baseada nas observações de campo. Foram escolhidos alunos que, preferencialmente, participavam ativamente das aulas, principalmente daquelas relacionadas à evolução e origem da vida e/ou demonstraram interesse por temáticas religiosas em conversas com colegas, leituras, entre outros. Seguindo os princípios da ética na pesquisa, foram distribuídos Termos de Consentimento Livre e

\footnotetext{
${ }^{4}$ Todos os nomes utilizados são fictícios.
} 
Esclarecido (TCLE) para os responsáveis, para os estudantes e para os professores, a fim de explicitar os objetivos da pesquisa e garantir o anonimato aos participantes.

No presente trabalho serão apresentados parte destes dados, a saber: notas a partir da observação de aulas e transcrições das entrevistas de quatro professores e de dez alunos. Seguindo as orientações de Braun e Clarke (2006), os materiais foram lidos repetidas vezes para que fosse aumentada a familiaridade com eles. Em seguida, foram codificados utilizando-se o software de análise de dados qualitativos Atlas.ti, utilizando-se tanto categorias acerca das relações entre evolução e criacionismo previamente discutidas por autores como Blancke et al. (2012), Cobern (1994; 1996; 2000), Scott (2009), Smith e Siegel (2004) e Smith (2010), quanto categorias construídas a partir das falas e observações obtidas ao longo da coleta de dados. Na etapa seguinte, os códigos gerados foram organizados em temas mais abrangentes que foram checados em relação aos diferentes trechos codificados e ao conjunto de dados como um todo. Posteriormente, os temas foram analisados a fim de compreender sua relação com o perfil dos sujeitos de pesquisa, suas concepções e reflexões. Finalmente, foram elaborados o presente texto e os mapas conceituais, destacando-se os principais temas, trechos que os exemplificam, sua relação com a pergunta da pesquisa e com a literatura da área além das representações visuais do modelo. O sexo, escola e religião dos professores e alunos entrevistados são resumidos nas Tabelas 1 e 2.

Tabela 1: Sexo, escola e religião dos professores.

\begin{tabular}{llll}
\hline PROFESSOR/A & SEXO & ESCOLA & RELIGIÃO \\
P1 & Masculino & Guarani & Sem religião \\
P2 & Feminino & Guarani & Católica \\
P3 & Feminino & Passaredo & Católica \\
P4 & Feminino & Guarani & Sem religião \\
\hline
\end{tabular}

Fonte: Os autores.

Tabela 2: Sexo, escola e religião dos alunos

\begin{tabular}{llll}
\hline ALUNO/A & SEXO & ESCOLA & RELIGIÃO \\
A1 & Feminino & Guarani & Evangélica Pentecostal \\
A2 & Masculino & Guarani & Católico \\
A3 & Feminino & Guarani & Evangélica Pentecostal \\
A4 & Masculino & Guarani & Católico \\
A5 & Masculino & Guarani & Ateu \\
A6 & Feminino & Passaredo & Evangélica Pentecostal \\
A7 & Feminino & Passaredo & Evangélica Pentecostal \\
A8 & Masculino & Passaredo & Católico \\
A9 & Feminino & Passaredo & Evangélica Pentecostal \\
A10 & Masculino & Passaredo & Sem religião \\
\hline
\end{tabular}

Fonte: Os autores.

A partir dos dados da pesquisa e na literatura da área, propomos um modelo para o diálogo em sala de aula baseado nos conceitos de "espaço de busca" (search space) de France 
(2011) e "discurso" (Diskurs) de Habermas (1984; 1989) entre professores e estudantes sobre o tópico de evolução. De acordo com France (2011), o modelo de espaço de busca está baseado na premissa de que o diálogo entre dois grupos só pode ocorrer sob circunstâncias específicas, isto é, quando há um "espaço” que permite aos participantes questionar uns aos outros e desenvolver certo entendimento comum. A autora defende que o espaço de busca consiste numa interseção, numa área virtual, dos componentes dos pontos de vista de duas comunidades. É nesse espaço de busca que as pessoas podem discutir e chegar a um acordo, apesar das diferenças de suas crenças, atitudes e comportamentos. A autora sugere que onde há similaridade nos elementos das visões das duas comunidades, a comunicação é possível. Entretanto, se não há tal semelhança, surge um espaço de busca no qual certo nível de entendimento deverá ser desenvolvido. Assim, quando houver similaridade de entendimento suficiente haverá possibilidade para o diálogo.

Essa referência dialoga com os trabalhos de Habermas $(1984,1989)$ sobre ação comunicativa e os atos de fala nas sociedades modernas. Para o filósofo alemão, a sociedade organiza-se numa estrutura intersubjetiva, que compreende esferas que se sobrepõem, na qual os agentes individuais interagem. Além disso, baseando-se em uma concepção pragmática da linguagem, argumenta que a função da fala é levar os interlocutores a um entendimento compartilhado e estabelecer um acordo intersubjetivo, o qual fornece as bases para suas ações posteriores: "alcançar o entendimento habita a fala humana como seu telos" (HABERMAS, 1984, p.287) ${ }^{5}$.

Para Habermas (1989, p.79), são comunicativas as interações nas quais "as pessoas envolvidas se põem de acordo para coordenar seus planos de ação, o acordo alcançado em cada caso medindo-se pelo reconhecimento intersubjetivo das pretensões de validez”. $\mathrm{O}$ filósofo identifica três pretensões de validez: (i) verdade, (ii) correção e (iii) sinceridade. A primeira consiste na ideia de que o que se propõe é verdadeiro, a segunda na de que é compatível com as normas apropriadas àquele contexto e a terceira na de que o falante é sincero sobre o significado ou a intenção do que é proposto. As duas primeiras pretensões serão avaliadas pela exposição de razões. Já a última, se baseará no comportamento e prática cotidiana do falante.

De acordo com Finlayson (2005), quando as pretensões de validade são tacitamente aceitas e satisfazem o ouvinte, a ação comunicativa é bem-sucedida. No entanto, quando não há um acordo sobre o que está sendo proposto, a verdade de uma asserção será avaliada no que Habermas chama de discurso (HABERMAS, 1984). Seu objetivo é encontrar um acordo

\footnotetext{
5 Tradução livre da versão em inglês "Reaching understanding inhabits human speech as its telos" (HABERMAS, 1984, p.287).
} 
racionalmente motivado, mesmo que isto não seja acessível. Na concepção habermasiana, discurso não é sinônimo de linguagem ou fala:

só me referirei a 'discurso' quando o significado de uma pretensão de validez forçar conceitualmente os participantes a suporem que um acordo racionalmente motivado pode, em princípio, ser alcançado, onde a expressão 'em princípio' expressa a condição idealizada: apenas se a discussão possa ser conduzida suficientemente aberta e com duração suficiente. (HABERMAS, 1984, p.42) ${ }^{6}$

Habermas (1989, p.112) destaca que o discurso pressupõe normas para que se desenvolva de forma que as razões utilizadas para defender as afirmações feitas pelos participantes possam ser questionadas:

\footnotetext{
1 - É lícito a todo sujeito capaz de falar e agir participar de Discursos.

2 - a. É lícito a qualquer um problematizar qualquer asserção.

b. É lícito a qualquer um introduzir qualquer asserção no Discurso.

c. É lícito a qualquer um manifestar suas atitudes desejos e necessidades.

3 - Não é lícito impedir falante algum, por uma coerção exercida dentro ou fora do Discurso, de valer-se de seus direitos estabelecidos em 1 e 2.
}

Tendo em vista os conceitos de Habermas (1984; 1989), o modelo que propomos baseia-se na ideia de que o professor, ao ensinar evolução, deve simultaneamente procurar atender às pretensões de validez em suas afirmações, bem como fazer com que as discussões desenvolvidas em sala atendam às regras do discurso. Nesse sentido, espera-se que o professor de biologia ensine evolução com o objetivo de explicar ao estudante porque a teoria evolutiva é aceita pelos cientistas como verdadeira. Assim, afirmações como "a teoria evolutiva é apenas uma teoria e tem tanto poder explicativo quanto qualquer outra ideia" ou "os cientistas questionam a teoria evolutiva em favor do design inteligente", críticas comuns feitas por determinados grupos criacionistas (SCOTT, 2009), não atenderiam à pretensão de validez de verdade.

Adicionalmente, seguindo as regras do discurso, todo estudante teria direito de manifestar sua opinião em sala de aula, inclusive crenças religiosas que, porventura, venham a entrar em conflito com a teoria evolutiva. Contudo, aqueles questionamentos que possam ser vistos como hipóteses científicas, podem vir a ser analisados de um ponto de vista científico ao longo do discurso. Suponhamos, por exemplo, que um aluno argumente que não pode aceitar as teorias científicas sobre a origem e evolução da vida porque, de acordo com a Bíblia, a Terra tem em torno de seis mil anos de idade. Esta afirmação pode ser questionada de um ponto vista científico, dado que há muitas evidências científicas de que nosso planeta seria muito mais antigo. No entanto, uma vez que afirmações metafísicas fogem do escopo da ciência, esta não pode ser usada para questioná-las (COBERN, 2000; SMITH; SIEGEL,

\footnotetext{
${ }^{6}$ Tradução livre da versão em ingles: "I shalI speak of "discourse" only when the meaning of the problematic validity claim conceptually forces participants to suppose that a rationally motivated agreement could in principle be achieved, hereby the phrase ' 'in principle" expresses the idealizing proviso: if only the argumentation could be conducted openly enough and continued long enough.” (HABERMAS, 1984, p. 42).
} 
2004). Assim, a existência da alma ou de Deus não devem ser alvo da análise de um ponto de vista científico, na aula de biologia.

Consequentemente, mais do que ter por objetivo converter as visões de um grupo em outro, o espaço de busca baseado no discurso deve consistir em uma oportunidade para cada grupo explorar outros pontos de vista. Deve haver a possibilidade de se concordar em discordar: por mais que dois grupos não concordem, ao menos são capazes de entender e discutir os pontos de vista um do outro, alcançando acordos sobre o significado de determinados conceitos. Assim, busca-se a ampliação das possibilidades de acesso a repertórios explicativos distintos, permitindo aos alunos fazer escolhas e mediações mais complexas. Um modelo de espaço de busca para a nossa pesquisa é apresentado a seguir (Figura 1):

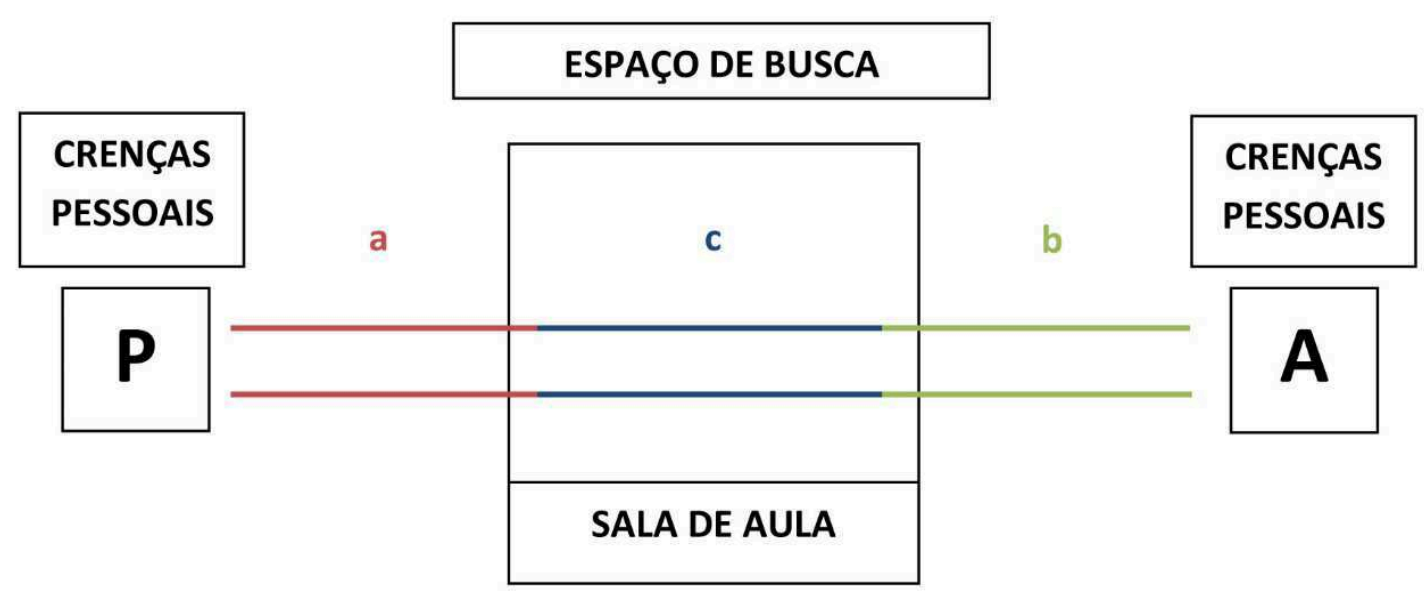

Figura 1 - Modelo do espaço de busca.

Fonte: Os autores.

A letra "P" representa o/a professor/a e "A", os/as alunos/as. Ambos possuem "Crenças Pessoais" sobre conceitos religiosos e científicos, os quais fundamentam as ideias que expõem em sala de aula durante os debates sobre evolução e criacionismo. As letras "a" e "b" representam o que eles disseram ser suas crenças particulares durante as entrevistas e, portanto, foram a fonte mais direta para os pesquisadores acessarem suas crenças pessoais. A letra "c", por sua vez, representa o que eles discutiram durante as aulas observadas, suas aproximações e distanciamentos na construção de entendimentos e acordos comuns.

O espaço de busca "ideal”, baseado nos dados de nossa pesquisa, envolveria três características: (i) coerência entre as crenças pessoais e o que é ensinado em sala de aula; (ii) abertura a outros pontos de vista; (iii) disponibilidade para discutir respeitosamente posições que não sejam as suas próprias. A característica “(i)” se justifica, como veremos mais adiante, pelo fato da inconsistência entre o que o docente acredita e o que ele afirma em sala de aula poder limitar a confiança dos estudantes. A segunda e a terceira características estão 
intrinsecamente ligados e envolvem o reconhecimento de que outras visões de mundo podem ser válidas em diferentes contextos e, portanto, não devem ser desprezadas.

\section{Resultados}

Todos os quatro professores entrevistados ensinaram evolução em suas aulas. Embora eles tenham tentado estimular comparações entre as ideias religiosas, o criacionismo e a teoria evolutiva, diversos fatores se apresentaram como obstáculos para uma discussão aprofundada, em que diferentes visões, tanto dos docentes quanto dos estudantes, fossem reconhecidas e valorizadas e, possivelmente, servissem para reflexões sobre a teoria evolutiva, as crenças religiosas e as formas como esses conhecimentos são produzidos, visando o entendimento da teoria evolutiva: (i) dificuldade em lidar com pessoas evangélicas pentecostais; (ii) insegurança ou hesitação em lidar com os temas sobre origem e evolução da vida e (iii) exposição das crença religiosa do professor aos estudantes.

Primeiramente, nenhum dos professores demonstrou, em suas entrevistas, ter facilidade de relacionar-se com fiéis pentecostais ou neopentecostais. O professor P1, por exemplo, em sala de aula, explicou que o criacionismo preconiza que Deus criou Adão e Eva e todo o planeta como está na Bíblia. Uma aluna evangélica, então, disse que acreditava na narrativa bíblica, ao passo que P1 retrucou que nada daquilo era científico, nem era comprovado. Ele afirmou que o mais importante era o conteúdo da disciplina de biologia e que não importava a religião de cada um em sala de aula. P1 acrescentou que, de acordo com o criacionismo, as espécies são imutáveis, que a realidade não seria dessa forma e que a teoria evolucionista é científica e a criacionista não. A aluna demonstrava, através de sua expressão facial, estar incomodada com o que o professor dizia e com a forma como ele o fazia.

P1 continuou a explicar porque discordava do criacionismo afirmando que "Dizem que Deus está entre as nuvens. Aí você pega um avião. Aí você passa de avião e não vê nada". A aluna olhou com uma expressão de estranhamento e afirmou que não pensava dessa forma e que, na verdade, existiriam vários céus. Constrangida, a estudante pediu para mudar de assunto, atitude também defendida por uma colega ao seu lado. No entanto, P1 respondeu que a aula era justamente sobre essa temática e continuou sua argumentação afirmando que para acreditar no criacionismo "basta provar, basta comprovar", isto é, se o criacionismo fosse "provado", ele o aceitaria. Ao final da aula, a aluna foi até a mesa do professor e tentou lhe explicar a sua crença de vários céus. P1 não lhe deu muita atenção, enquanto procurava levantar de sua cadeira e deixar a sala de aula.

P1 se declarou sem religião e, pelo conteúdo de sua entrevista, não acreditava em um Deus como agente criador. Nesse sentido, sua visão da relação entre evolução e criacionismo era mais direta e menos complexa do que a dos professores que possuíam uma crença 
religiosa, como veremos mais adiante. P1 separou claramente evolução de criacionismo, identificando a primeira com uma aproximação da verdade e o segundo, consequentemente, como algo falso. Ele afirmou que após passar por muitas religiões e viver um momento de conflito pessoal durante o início da faculdade, afastou-se das crenças religiosas e diz que entender a realidade lhe trouxe mais conforto e sentido à vida do que acreditar em uma entidade transcendental. Ainda assim, disse que não se incomodava em falar de Deus, pois, Ele não seria uma figura concreta de aparência humana, como para o Cristianismo, mas sim uma sensação boa. Sua visão pode ser resumida no mapa conceitual abaixo (Figura 2).
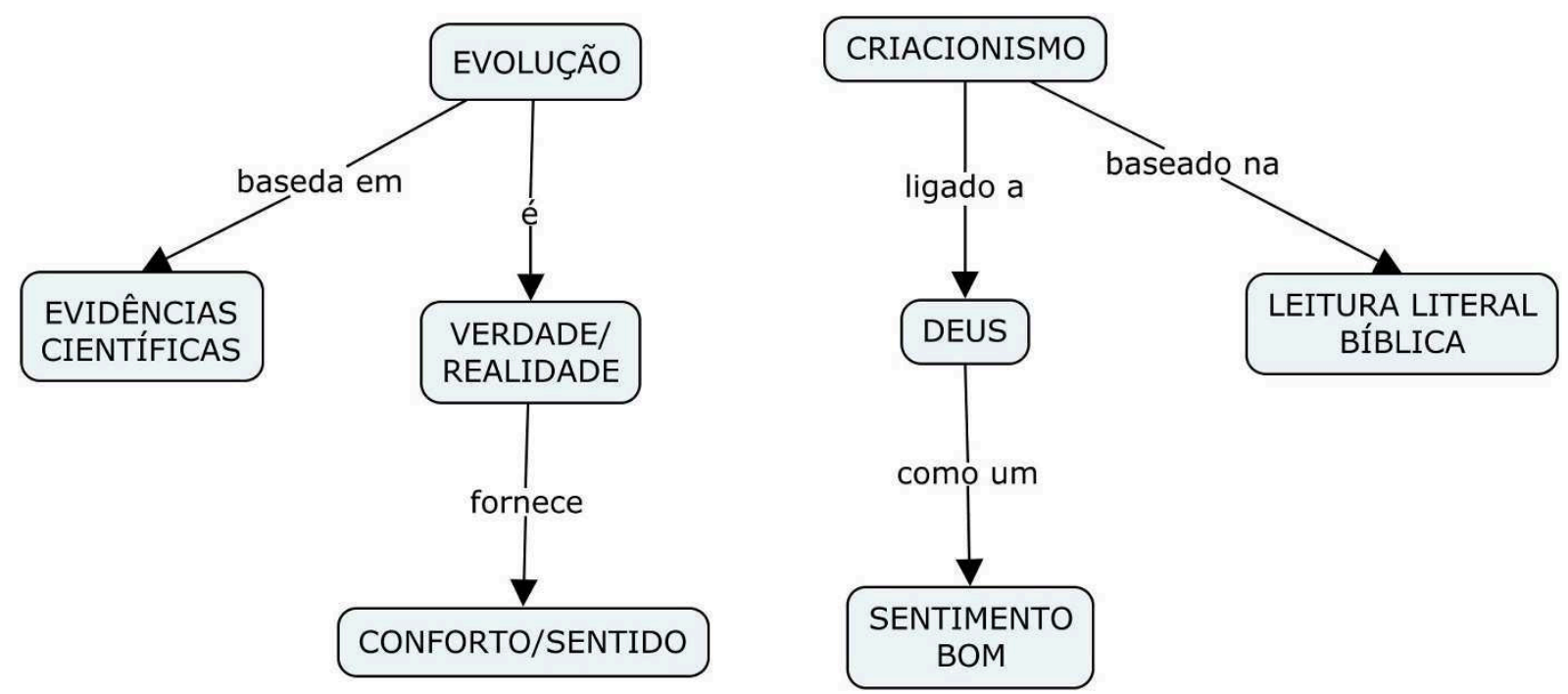

Figura 2: Concepções de P1 sobre evolução e criacionismo.

Fonte: Os autores.

Um segundo obstáculo a ser destacado é a insegurança demonstrada por P2 e P3 diante da relação entre a crença religiosa dos estudantes e os conceitos da teoria evolutiva. Em uma de suas aulas, P2 perguntou aos alunos como eles/as pensavam que a vida teria surgido na Terra. Uma aluna logo lhe respondeu: "Para mim, foi Deus". A professora olhou para a estudante, mas manteve-se em silêncio com uma expressão que indicava dúvida e seguiu adiante com o conteúdo da aula, sem responder diretamente ou problematizar o que sua estudante havia dito.

A professora católica não-praticante $\mathrm{P} 2$, em sua entrevista, mostrou incertezas quanto à sua visão de mundo. Ela argumentou criticando alguns elementos do pensamento científico e flexibilizando conceitos religiosos. Sua formulação final misturou conceitos de ambas as matrizes de influência, sendo difícil estabelecer fronteiras claras entre elas. A ideia de um universo de grandes dimensões a fazia pensar que não estamos sozinhos nele. Esse sentimento fazia com que ela acreditasse que existiria Deus ou uma força superior, com a qual se conectaria. Esta entidade transcendental teria atuado na criação do universo e da Terra, através de fenômenos que poderiam ser explicados por diferentes teorias, como o Big Bang, a 
evolução e o criacionismo. Nesse sentido, P2 utilizou o conceito de teoria de maneira híbrida, ora como uma explicação sem maior fundamentação em evidências, como quando se referiu às teorias científicas de origem da vida: "eu acho que são teorias mesmo, mas ninguém tava lá, ninguém pode provar absolutamente nada", ora como algo que confere validade a um determinado pensamento, quando justificou porque ensina o criacionismo: "porque é uma teoria, eu não posso negar essa teoria. É a mais antiga, é a que nos acompanha”. Sua visão pode ser resumida no seguinte mapa conceitual (Figura 3).

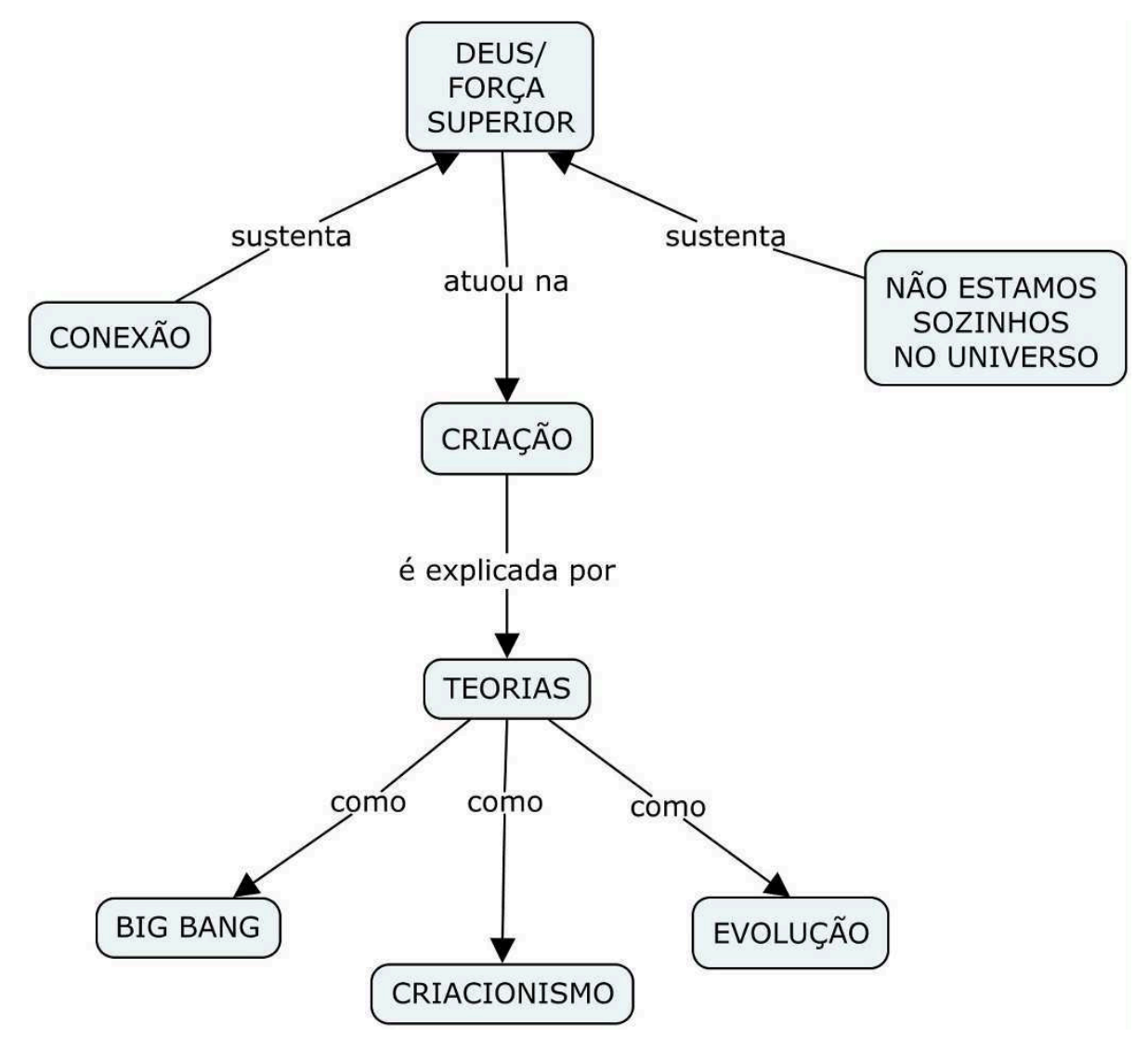

Figura 3: Concepções de P2 sobre evolução e criacionismo.

Fonte: Os autores.

Já P3, por sua vez, afirmou em sua entrevista que não rejeitava a evolução nem o criacionismo, mas acreditava que Deus seria a causa do processo evolutivo: "Porque é tudo tão perfeito, tão sincronizado... Cientificamente, a gente não tem resposta. Então eu acredito que a resposta seja Deus, que esteja ali manipulando isso". No entanto, durante sua a aula, ela hesitou em reafirmar sua opinião. Quando questionada diretamente por uma aluna evangélica pentecostal se acreditava no criacionismo ou na evolução, P3 disse que "pelas evidências, pelas provas que a gente estuda, eu acredito na evolução". A estudante fez uma expressão que parecia indicar que não estava surpresa e P3 continuou dizendo, "mas eu também me questiono muito". Mesmo assim, a estudante não mudou sua expressão facial.

A visão pessoal de P3 sobre a evolução e o criacionismo estava baseada na flexibilização dos conhecimentos científico e religioso. Ela aceitava que os seres vivos se 
transformam ao longo do tempo, porém acreditava que a ciência não conseguiria explicar suficientemente essas mudanças, citando o livro A Caixa Preta de Darwin ${ }^{7}$, e, ainda, que seria Deus a causa do processo evolutivo, demonstrando a perspectiva do evolucionismo teísta (SCOTT, 2009). Por outro lado, levantava críticas à Bíblia, a qual não lia de forma literal e procurava fornecer explicações científicas para determinadas passagens bíblicas. Assim, em sua entrevista, ela disse que os dias relatados no Gênesis não seriam intervalos de vinte e quatro horas, mas sim longos períodos de tempo: "Seriam muitos e muitos milhões de anos nessa escala aí de sete dias". Suas concepções podem ser resumidas no mapa conceitual da Figura 4.

Um terceiro ponto relaciona-se a P4, que expôs sua visão sobre o assunto aos alunos sem que eles a tivessem questionado nem que algum tipo de debate estivesse em curso. Ela afirmou que "para a ciência, a Terra era um planeta quente e sem seres vivos. Para a religião, era sem forma e vazio. Viu como batem?". Alguns alunos que costumavam ser mais participativos em sua aula concordaram com a colocação da professora que continuou a aula afirmando que religião e ciência não entram em conflito.

A professora P4 declarou que não tinha religião e que só acreditava em Deus e em Jesus. Ao longo de sua entrevista, ela disse que já tinha sido católica e evangélica, mas que atualmente estava se aproximando do espiritismo porque, recentemente, tinha visto vultos e sentido a presença de pessoas já falecidas. Assim, embora não estivesse filiada a nenhuma denominação religiosa específica, diferentes elementos do cristianismo atravessavam suas ideias sobre Deus e sobre a origem e evolução dos seres vivos em nosso planeta. Ela não se identificava nem com a leitura literal da Bíblia, nem com uma visão especificamente evolucionista, preferindo adotar uma visão de que a evolução ocorreria, mas seria causada por Deus e envolveria uma dimensão espiritual. Sua ideia de Deus sofria influências de conceitos científicos, judaico-cristãos e espíritas, mas a professora ainda demonstrava algumas incertezas. Sua visão pode ser resumida no mapa conceitual da Figura 5. Buscamos representar a complexidade de seu pensamento e as conexões que a professora estabelece entre conceitos científicos e religiosos através do cruzamento das setas que saem de "evolução" e "criacionismo" para "evolução espiritual” e "evolucionismo teísta”.

\footnotetext{
${ }^{7}$ De autoria de Michael Behe, defensor do design inteligente, o livro aponta supostas limitações da teoria neodarwinista da evolução. Suas alegações sofreram amplas críticas da comunidade acadêmica e o design inteligente não é considerado pela maioria dos cientistas como teoria científica. $\mathrm{O}$ design inteligente é um movimento surgido entre as décadas de 1980 e 1990 que nega a teoria evolutiva, afirmando que os seres vivos são complexos demais, sendo necessária a atuação de um planejador (ou designer) para que eles existam da forma como são (SCOTT, 2009).
} 


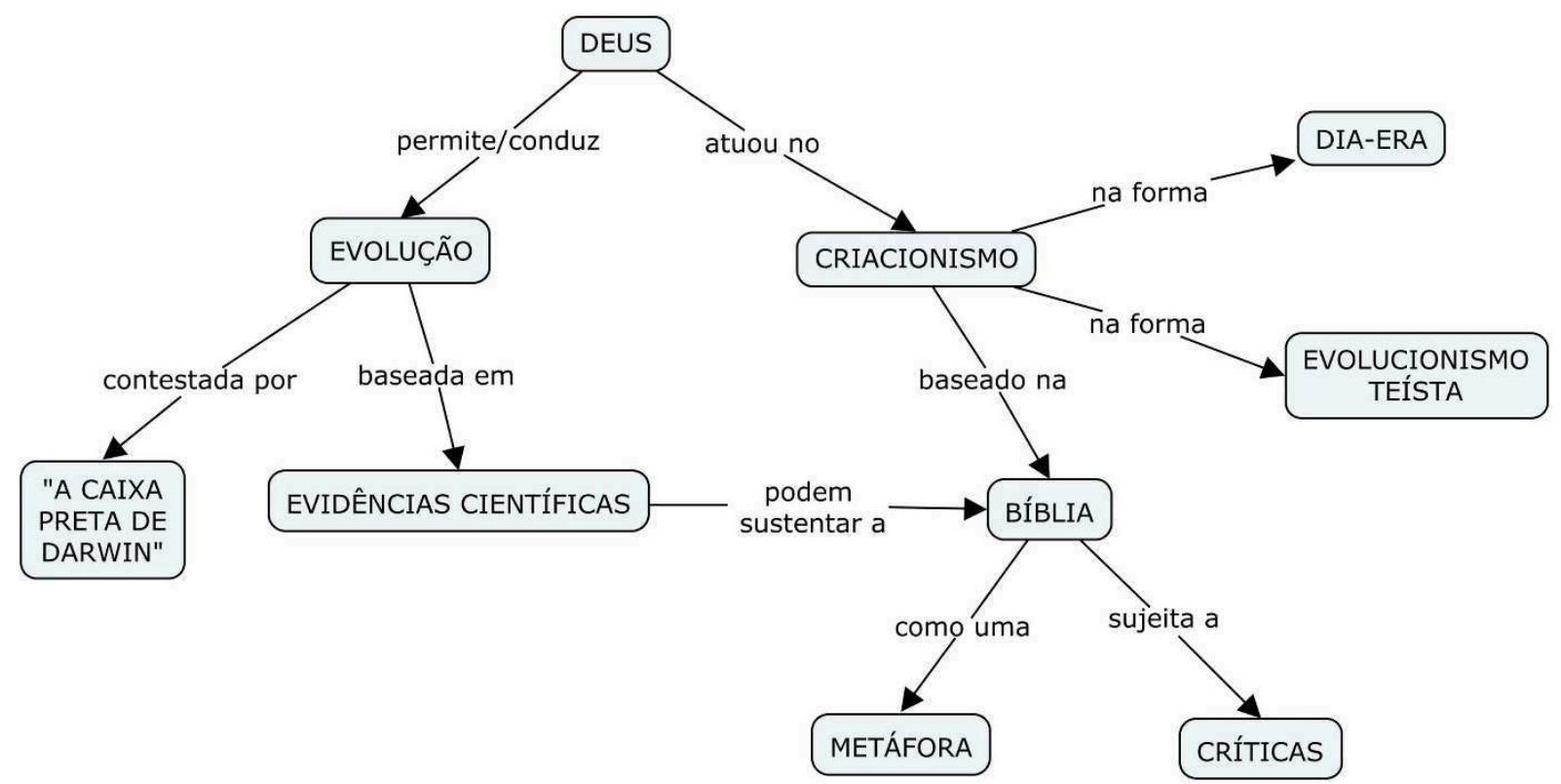

Figura 4: Concepções de P3 sobre evolução e criacionismo.

Fonte: Os autores.

No que concerne aos estudantes, sete deles (todos os cinco evangélicos pentecostais além de A2, católico, e A10, sem religião) afirmaram acreditar na criação dos seres humanos, de outros seres vivos e do universo como descrito na Bíblia. Quatro estudantes (A5, ateu; A6 e A7, evangélicas pentecostais; A8, católico) referiram-se à evolução dizendo que o homem veio do macaco. A6, no entanto, rejeitava a teoria evolutiva dizendo "porque se surgisse do macaco, o macaco ia se transformar em homem com o decorrer do tempo e não aconteceu isso". Chama atenção ainda o fato de que cinco alunos (A1 e A7, evangélicas pentecostais; A2, A8, católicos; A10, sem religião) se referiram ao Big Bang como uma bola de fogo, a explosão do sol ou um meteoro que caiu na Terra. Por fim, dois estudantes (A1, evangélica pentecostal, e A4, católico) dizem que já tiveram professores de biologia que admitiam ter religião, característica que, segundo os alunos, facilitaria as discussões sobre evolução. 


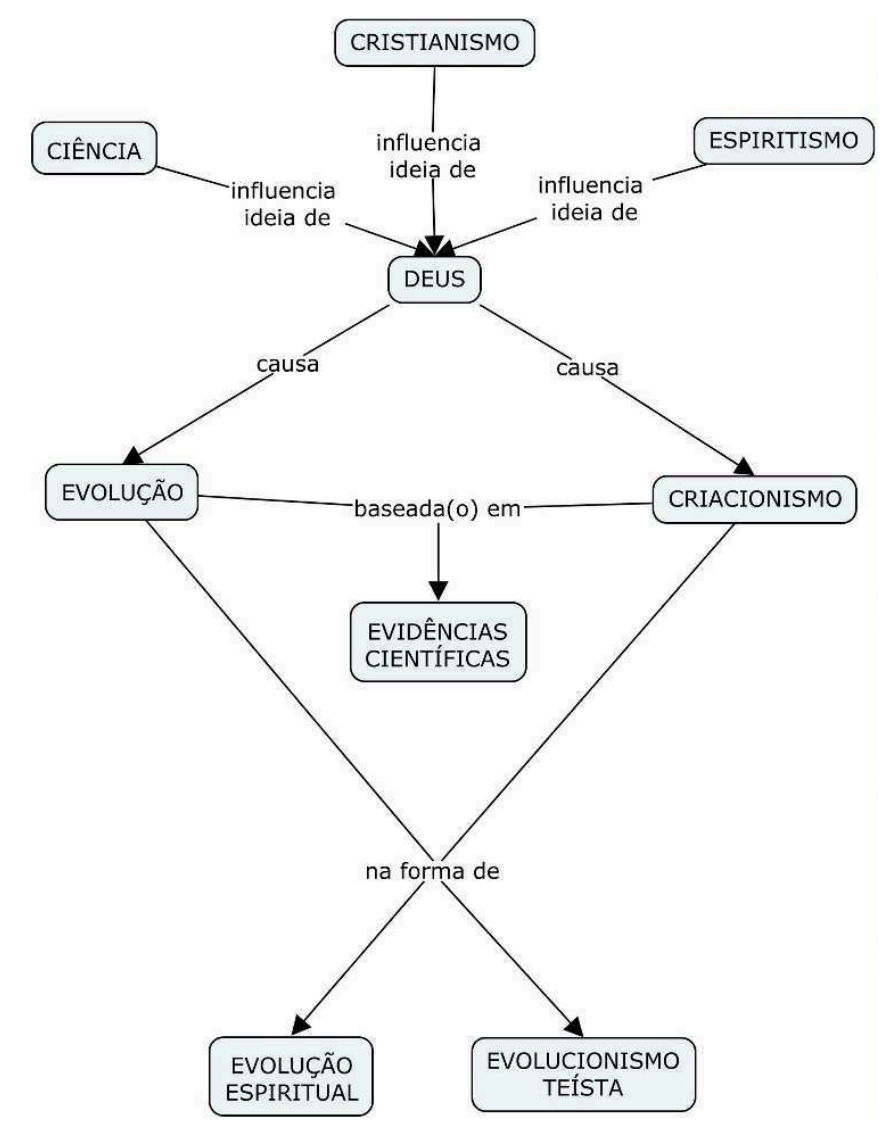

Figura 5: Concepções de P4 sobre evolução e criacionismo.

Fonte: Os autores.

\section{Discussão}

A partir do modelo e dos dados descritos anteriormente, apresentamos as representações do modelo de espaço de busca para cada caso aqui analisado. A Figura 6 mostra o caso de P1, cujos pontos de vista foram semelhantes em sua entrevista e em suas aulas. Entretanto, como ele desvalorizou a crença da aluna, não houve, naquele momento, possibilidade de sobreposição de entendimento comum. Uma vez que não esteve aberto às ideias da estudante, não foi possível desenvolver um espaço de busca em que um pudesse se esforçar para compreender a visão de mundo do outro. É importante perceber que P1, ao argumentar que a existência de Adão e Eva não era científica nem comprovada, sugeria que o que não é científico seja falso, o que possivelmente causou incômodo na estudante, uma vez que tais elementos faziam parte de sua crença e de sua visão de mundo. Além disso, ao associar ciência à comprovação, dá sinais de que acreditava que a ciência poderia gerar conhecimentos capazes de serem provados e, por consequência, verdadeiros e impossíveis de serem negados. Dessa maneira, implicitamente, afirmava que a ciência conseguiria identificar o mundo como ele realmente é e a religião não. Nesse sentido, suas estratégias pedagógicas e discursivas em sala de aula se correlacionariam com suas concepções acerca da evolução e do criacionismo. Assim como ele os considerava como conceitos plenamente distintos, sendo um verdadeiro e o outro não, ele também argumentou desta forma durante suas aulas. O não- 
desenvolvimento de um espaço de busca decorreu da não-abertura à visão da aluna, diversa da sua.

Afirmando que estava se propondo a tratar do conteúdo e não da religião, P1 ancorouse em uma visão de que o currículo deve ser seguido tanto por professores quanto por alunos sem ser questionado e indicou que a religião não deve ser discutida em sala de aula. Ao argumentar que se alguém andar de avião por entre as nuvens não verá Deus, demonstrou estar próximo de uma visão da ciência como resultado da observação direta de fenômenos naturais. Além disso, deixou de lado possíveis interpretações religiosas que vissem a imagem de céu como transcendental ou metafórica, como a aluna tentou sugerir. Em seguida, a insistência em tratar o assunto, apesar do apelo das estudantes para que mudasse, fez com que elas se sentissem ainda menos à vontade de participar.

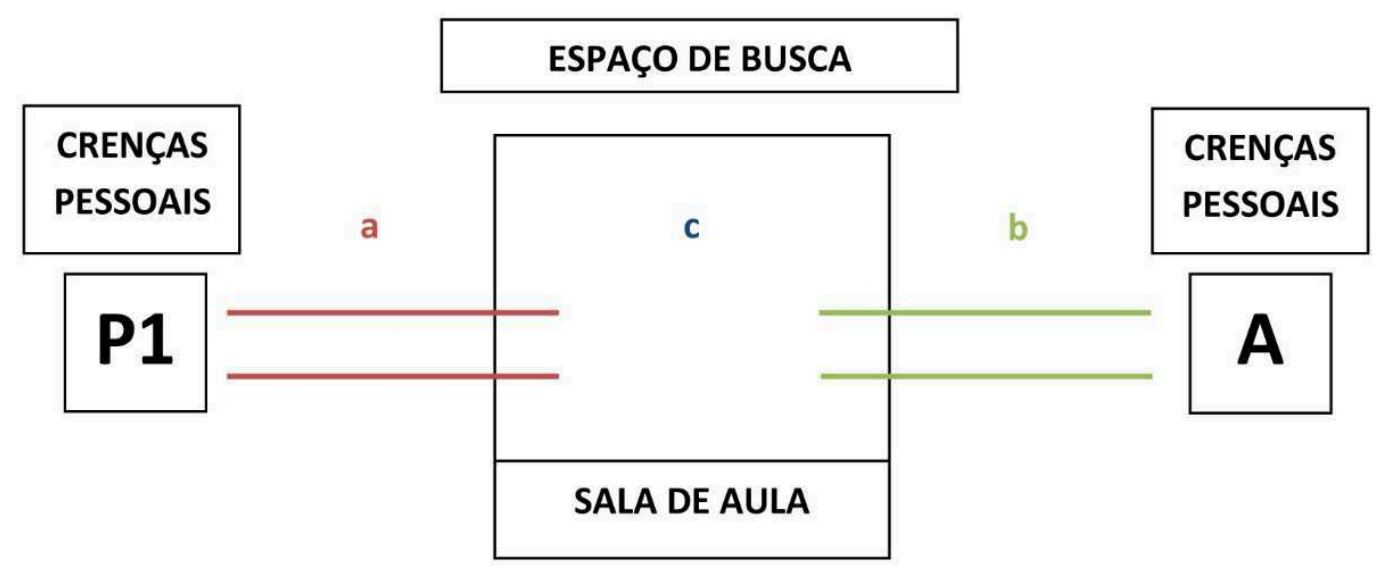

Figura 6. Modelo do espaço de busca para P1.

Fonte: Os autores.

É interessante notar ainda, que, embora o professor tenha sinalizado que religião não faz parte da aula, ele discutiu conceitos religiosos (como céu e Paraíso) durante a mesma e frisou que aquele era o tema da aula do dia. Nesse sentido, a religião só foi tratada por P1 para criticar seus pressupostos e nunca como possibilidade válida para discutir a origem da vida.

Por fim, ao afirmar que para aceitar o criacionismo bastava comprová-lo, retomou a oposição entre ciência - verdadeira - e criacionismo - falso - bem como a concepção de que o conhecimento científico não daria margens para refutações. Essa ideia se aproxima do positivismo e do cientificismo (CHALMERS, 1999) e é apontada por Gil-Pérez et al. (2001) como uma visão bastante difundida e presente na formação de professores de ciências, tratando o conhecimento científico como fruto da observação e experimentação "neutras" e como sendo ahistórico e aproblemático. Esta postura causou desconforto às alunas, pois claramente desvalorizava suas crenças e foi reforçada pelo tom irônico com que tratou a fala da estudante ao final da aula. Pelos motivos expostos, não houve a construção de um espaço de busca e, por isso, o segmento de reta correspondente à letra "c" está ausente do esquema. 
A figura 7 representa a situação de P2. Suas crenças privadas eram coerentes com seu discurso em sala de aula. No entanto, ela pareceu insegura sobre como lidar com as crenças dos alunos. Quando sua aluna afirmou que na visão dela, a vida havia sido criada por Deus, P2 fez uma expressão de dúvida e não fez nenhum comentário. É possível que a professora percebesse os temas religiosos como difíceis de serem debatidos, tendo em vista tensões pelas quais ela mesma já havia passado anteriormente ${ }^{8}$. Além disso, assim como no caso de P1, é possível perceber correlações entre as concepções pessoais de P2 e suas estratégias didáticas. Sua visão pessoal articulava elementos do conhecimento científico e do conhecimento religioso, mas a própria professora reconheceu que possuía incertezas. Essas limitações influenciavam sua postura em sala de aula, de modo que ela não se aprofundava no debate das ideias da educanda. Um espaço de busca poderia ser construído, tendo em vista que a estudante expôs sua crença aparentemente de boa fé e a professora poderia relacioná-la aos conteúdos em sala de aula. No entanto, esta construção demandaria mudanças das estratégias didáticas da professora para se relacionar com a crença dos educandos. Tal limite foi representado pelo tracejado correspondente à letra "c".

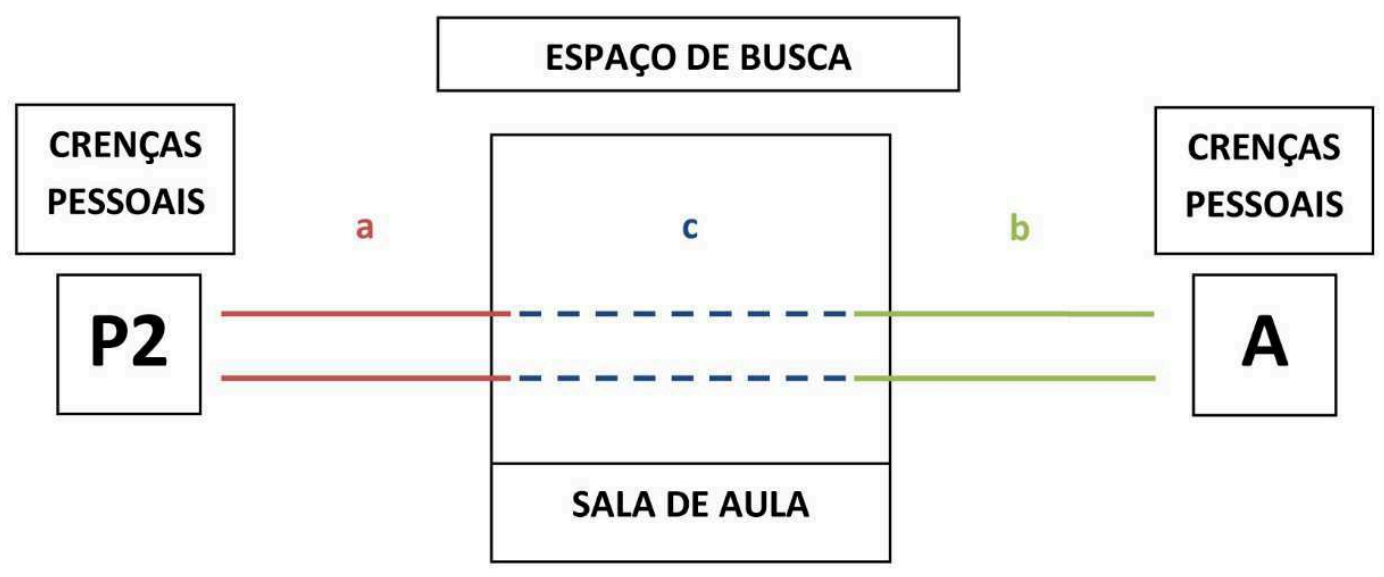

Figura 7. Modelo do espaço de busca para P2.

Fonte: Os autores.

A Figura 8 mostra a representação para P3. Suas crenças privadas não coincidiam com o que ela dizia em sala de aula. Em sua entrevista ela afirmou que acreditava que a evolução ocorria, mas que era Deus quem a conduzia e, em sua aula, por outro lado, afirmou que acreditava na teoria evolutiva, sem fazer nenhuma menção à possível atuação de Deus. Embora P3 tenha tentado estabelecer uma discussão com os alunos, não conseguiu deixar claro seu ponto de vista, o que afetou a construção do espaço de busca. Tal qual P1 e P2, é

\footnotetext{
${ }^{8}$ P2 afirmou em sua entrevista que já viveu situações de conflito em sala de aula em relação à origem da vida e evolução. Em uma delas, uma aluna teria se levantado com a Bíblia em mãos e disse que a teoria evolutiva era uma mentira e a verdade estava na Bíblia. P2 disse que, em resposta, convidou a turma a ler a Bíblia e discutir o criacionismo. Esse episódio aponta no sentido da formação de um espaço de busca. Porém, como não o observamos, não possuímos evidências para discuti-lo mais profundamente.
} 
possível perceber que as concepções pessoais de P3 também se relacionavam com sua prática pedagógica. Procuramos representar a inconsistência de seu discurso entre a entrevista e a atuação em sala de aula pelo tracejado correspondente à letra "a" e os limites na construção do espaço de busca pelo tracejado e pontilhado em relação à letra "c".

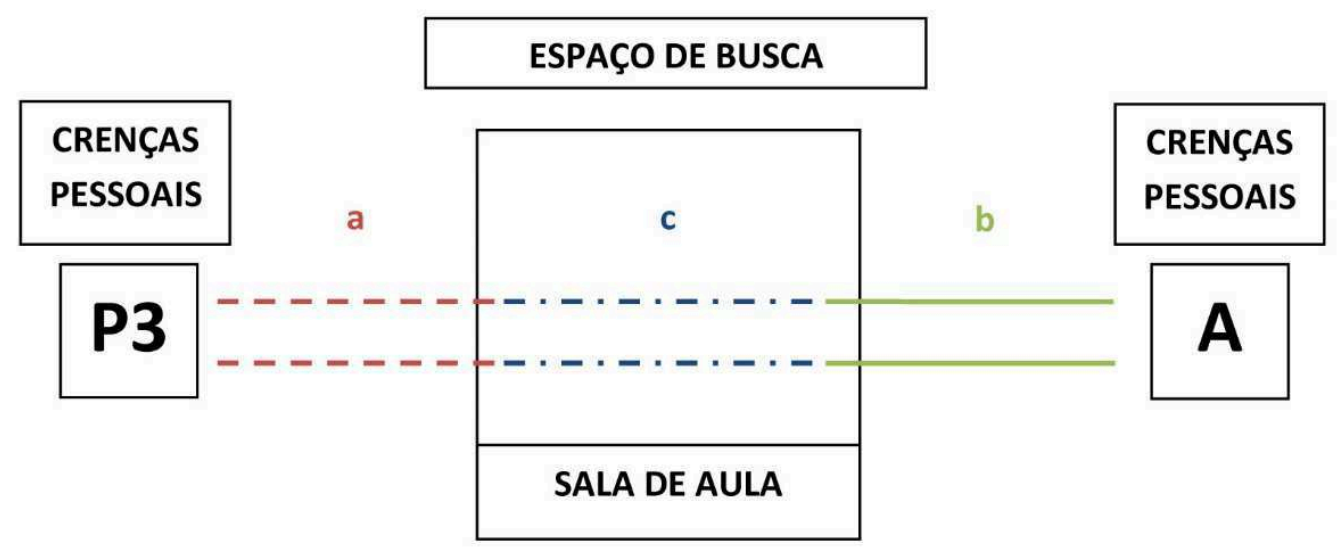

Figura 8. Modelo do espaço de busca para P3.

Fonte: Os autores.

A figura 9 representa os dados de P4. Suas crenças privadas corresponderam ao que ela diz em sala de aula. No entanto, ela não promoveu um debate com os alunos, apenas expôs sua visão. Por conseguinte, houve um potencial para o espaço de busca, embora este não tenha sido desenvolvido, mesmo que alguns dos estudantes tenham concordado com ela. Seria necessário que suas opiniões fossem abertas o suficiente para que os alunos se envolvessem em uma discussão construtiva, ainda que pudessem vir a discordar dela. Além disso, ao expor sua crença pessoal, a professora, pela posição de poder que ocupava dentro da sala de aula, corria o risco de ser considerada pelos alunos como a melhor ou a única opção possível. Nesse sentido, procuramos representar tal limitação na construção do espaço de busca através de segmentos de reta que não se encontram e que possuem um tom mais claro do que o do modelo "ideal". Havia a possibilidade de promover o diálogo em sala de aula, todavia esta não se concretizou.

Em relação aos estudantes, as crenças religiosas que realizam uma leitura literal da Bíblia aparentaram ser um dos principais obstáculos nas realidades estudadas. Nas turmas observadas, houve poucas situações de conflito explícito, porém as entrevistas revelaram que os alunos preferiam, muitas vezes, permanecer em silêncio e apenas estudar sobre evolução o suficiente para fazer provas e testes. Tal "compartimentalização" foi chamada por Cobern (1996) de "apartheid cognitivo", já tendo sido relatado em outras pesquisas (BLACKWELL et al., 2003; FONSECA, 2005; EL-HANI; SEPULVEDA, 2009). Outras questões, como afirmar que os seres humanos vieram dos macacos e o Big Bang, parecem ser de difícil compreensão independentemente da religião do educando, uma vez que estudantes de diferentes crenças 
apresentaram tais concepções. Resultados semelhantes também foram apontados por outras pesquisas (SANTOS, 2002; BLANCKE et al., 2012).

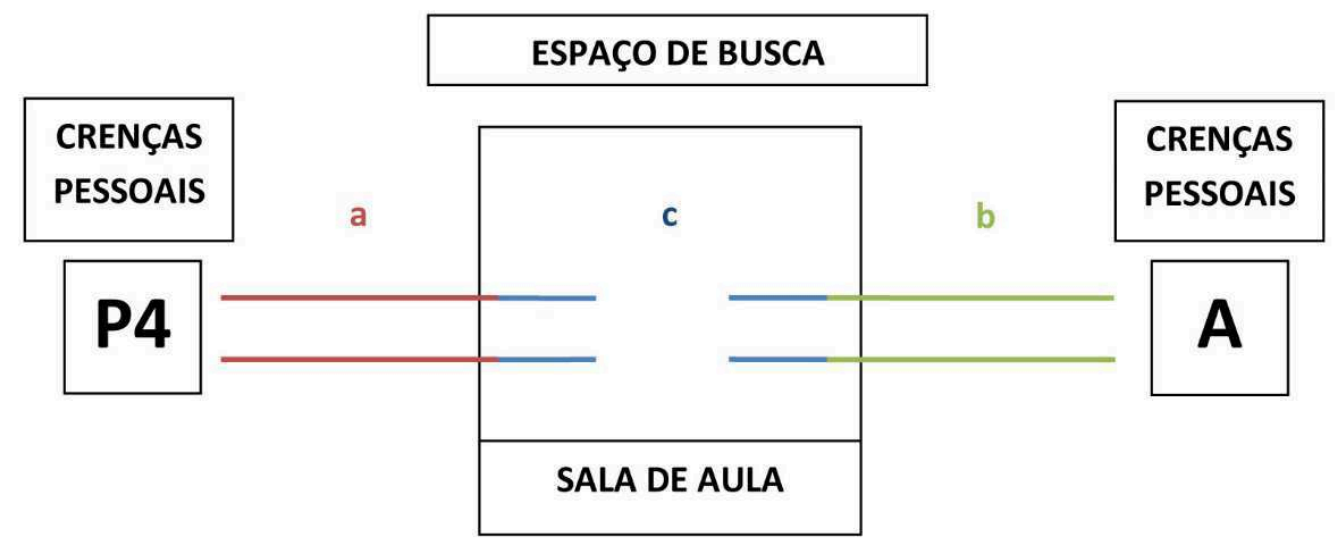

Figura 9. Modelo do espaço de busca para P4.

Fonte: Os autores.

Tendo em vista a importância das crenças religiosas para a construção de visões de mundo, as quais não deveriam ser vistas como erros conceituais ou concepções alternativas, Cobern (1994) defende que o objetivo do ensino de ciências deve ser o entendimento da ciência e não a mudança de crença. Tal pensamento também é defendido por outros autores da área (SMITH; SIEGEL, 2004; EL-HANI; MORTIMER, 2007; REISS, 2008) e, apoiados nos mesmos, propomos um modelo que visa estimular o diálogo em sala de aula, e não tentar "substituir" crenças religiosas em pensamento científico.

É fundamental ressaltar ainda, que a presença da religião na escola pública brasileira é permeada por tensões e disputas (CUNHA, 2007). Se, por um lado, a Constituição Federal de 1988 preconiza a laicidade do estado, a garantia do ensino religioso também na Carta Magna e seus desdobramentos em diversas realidades, inclusive com situações de preconceitos explícitas já documentadas, lançam desafios para a educação básica, inclusive o ensino de ciências. Como defende Caputo (2008), a escola pública deva ser laica, não havendo ensino religioso de nenhuma forma. Contudo, devemos ter em mente que sempre teremos alunos religiosos e que a religião não é uma roupa da qual se despem ao entrar na escola. Logo, é preciso repensar a relação da escola com as diferentes religiões. No caso do ensino de evolução, essa tarefa não pode ignorar, contudo, as diferenças entre o conhecimento científico e o religioso, sob risco de se comprometer a compreensão da natureza da ciência (EL-HANI; MORTIMER, 2007).

\section{Conclusão}

Em conclusão, nesse trabalho procuramos identificar e analisar possíveis conflitos e relações entre evolução e criacionismo em aulas de biologia em contextos de grande presença 
pentecostal e neopentecostal. Os dados obtidos a partir de entrevistas e observações em sala de aula indicam que há fatores das crenças e práticas pedagógicas de professores que podem contribuir para o desenvolvimento de propostas que visem o entendimento da teoria evolutiva e não a mudança de crença dos estudantes.

Nesse sentido, procuramos desenvolver, apoiados nos trabalhos de Habermas (1984; 1989) e France (2011), um modelo de espaço de busca, que procura ressaltar as posturas de docentes e estudantes quanto a essa temática em sala de aula. Nossos dados sugerem que há fatores que podem contribuir para a criação de um espaço de busca: i) a consistência entre as crenças particulares e o que é praticado em sala de aula e ii) a abertura às crenças de outras pessoas. Já fatores como i) a dificuldade em lidar com pessoas de crenças criacionistas, ii) a aproximação de uma visão cientificista e iii) a inconsistência entre as crenças particulares e prática pedagógica parecem dificultar sua construção. O professor ao declarar suas próprias crenças religiosas parece contribuir para a discussão, embora tal fato possa se apresentar como problemático. Este espaço de busca oferece um modelo para o diálogo em classe sobre a evolução, o que pode ajudar os alunos na compreensão da teoria evolutiva e ajudar os professores a se aproximarem dos contextos de seus alunos.

Cabe destacar que o modelo aqui desenvolvido se baseia nas contribuições de Habermas. No entanto, a ideia de discurso na obra do filósofo alemão pressupõe uma relação de igualdade de poder, ou que essa seja buscada ao máximo. Dado que há uma diferença de poder entre estudantes e professor na sala de aula, dificilmente as condições destacadas por Habermas seriam plenamente atendidas. Contudo, as ideias defendidas por este autor e utilizadas para basear nosso modelo podem atuar como um horizonte a ser perseguido por docentes e educandos, tendo em vista a importância da liberdade de pensamento e crença em uma perspectiva de ensino de evolução voltada para o seu entendimento.

\section{Agradecimentos}

Os autores agradecem ao CNPq e à CAPES pelo financiamento, a Luís Fernando Dorvillé, que contribuiu com comentários fundamentais a uma versão inicial deste artigo, e aos pareceristas pelas observações e sugestões indicadas.

\section{Referências}

ABRAPEC; SBENBIO. Carta aberta contra o Projeto de Lei 8099/2014, 2014.

Disponível em http://www.abrapec.ufsc.br/wp-content/uploads/2014/11/documentoconjunto-SBEnBio- ABRAPEC-final-12-1.pdf. Acesso em: 09/04/2015

ALMEIDA, R. D. A Igreja Universal e seus demônios : um estudo etnográfico. São Paulo, SP: Editora Terceiro Nome, 2009. 
BLACKWELL, W. H.; POWELL, M. J.; DUKES, G. H. The problem of student acceptance of evolution. Journal of Biological Education, v. 37, n. 2, p. 58-67, 2003.

BLANCKE, S. DE SMEDT, J.; DE CRUZ, H.; BOUDRY; M.; BRAECKMAN, J. The Implications of the Cognitive Sciences for the Relation Between Religion and Science Education: The Case of Evolutionary Theory. Science \& Education, v. 21, n. 8, p. 1167-1184, 2012.

BRASIL. Constituição da República Federativa do Brasil. Brasília: Secretaria Especial de Editoração e Publicações do Senado Federal, 2010.

BRASIL. Parâmetros Curriculares Nacionais Ensino Médio Parte III - Ciências da Natureza, Matemática e suas Tecnologias. Brasília: MEC, 1998.

BRASIL. Orientações Curriculares para o Ensino Médio - Ciências da Natureza, Matemática e suas Tecnologias. Brasília: MEC, 2006.

BRASIL. Projeto de Lei No. 8099: Ficam inseridos na grade curricular das Redes Pública e Privada de Ensino, conteúdos sobre Criacionismo. Congresso Nacional. Brasília 2014.

BRAUN, V.; CLARKE, V. Using thematic analysis in psychology. Qualitative Research in Psychology, v. 3, n. 2, p. 77-101, 2006.

CHALMERS, A. F. What is this thing called science? 3rd. Indianapolis: Hackett Pub., 1999.

COBERN, W. W. Point - Belief, Understanding, and the Teaching of Evolution. Journal of Research in Science Teaching, v. 31, n. 5, p. 583-590, 1994.

COBERN, W. W. Worldview theory and conceptual change in science education. Science Education, v. 80, n. 5, p. 579-610, 1996.

COBERN, W. W. The Nature of Science and the Role of Knowledge and Belief. Science \& Education, v. 9, n. 3, p. 219-246, 2000.

CUNHA, L. A. Sintonia oscilante: religião, moral e civismo no Brasil - 1931/1997. Cadernos de Pesquisa, v. 37, n. 131, p. 285-302, 2007.

DOBZHANSKI, T. Nothing in Biology Makes Sense except in Light of Evolution. American Biology Teacher, v. 35, n. 3, p. 125-129, 1973.

DORVILLÉ, L.; SELLES, S. Conflitos e tensões entre ciência e religião nas visões de mundo de alunos evangélicos de uma licenciatura em ciências biológicas. In: VIII CONGRESO INTERNACIONAL SOBRE INVESTIGACIÓN EN LA DIDÁCTICA DE LAS CIENCIAS. Anales del VIII Congreso Internacional Sobre Investigación En La Didáctica De Las Ciencias. Barcelona: 2757 - 2761 p. 2009.

EL-HANI, C. N.; MORTIMER, E. F. Multicultural education, pragmatism, and the goals of science teaching. Cultural Studies of Science Education, v. 2, n. 3, p. 657-702, 2007.

EL-HANI, C. N.; SEPULVEDA, C. The relationship between science and religion in the education of protestant biology preservice teachers in a Brazilian university. Cultural Studies of Science Education, v. 5, n. 1, p. 103-125, 2009. 
FINLAYSON, J. G. Habermas: a very short introduction. Oxford; New York: Oxford University Press, 2005. 156 p.

FONSECA, L. Religião popular: O que a escola tem a ver com isso? Pistas para repensar o ensino de ciências. 2005. 250 Tese (Doutorado). Faculdade de Educação, UFRJ, Rio de Janeiro.

FRANCE, B. How Post Normal views of science have contributed to a model of communication about biotechnology. Futures, v. 43, n. 2, p. 166-172, 2011.

FRESTON, P. Protestantes e política no Brasil: da Constituinte ao impeachment. 1993. Tese (Doutorado). IFCH, Unicamp, Campinas.

GIL-PÉREZ, D.; MONTORO, I. F.; ALÍS, J. C.; CACHAPUZ, A.; PRAIA, J. Para uma imagem não deformada do trabalho científico. Ciência \& Educação, v. 7, n. 2, p.125-153, 2001.

HABERMAS, J. R. The theory of communicative action. Boston: Beacon Press, 1984.

HABERMAS, J. R. Consciência moral e agir comunicativo. Rio de Janeiro: Tempo Brasileiro, 1989.

IBGE. Censo Demográfico 2010: Características gerais da população, religião e pessoas com deficiência. Rio de Janeiro: IBGE, 2012.

MALAFAIA, S. Criação x Evolução: quem está com a verdade? Rio de Janeiro: Editora Central Gospel, 2009.

MARIANO, R. Neopentecostais: sociologia do novo pentecostalismo no Brasil. São Paulo, SP: Edições Loyola, 1999. 246 p.

MAYR, E. The growth of biological thought: diversity, evolution, and inheritance.

Cambridge, Mass.: Belknap Press, 1982.

MENDONÇA, A. G. Evangélicos e pentecostais: um campo religioso em ebulição. In: TEIXEIRA, F.; MENEZES, R. (Ed.). As Religiões no Brasil: Continuidades e rupturas. Petrópolis: Vozes, 2006. p. 89-110.

NUMBERS, R. L. The creationists: from scientific creationism to intelligent design. Expanded. Cambridge, Mass.: Harvard University Press, 2006.

REISS, M. Should science educators deal with the science/religion issue? Studies in Science Education, v. 44, n. 2, p. 157-186, 2008.

REISS, M. Science and religion: implications for science educators. Cultural Studies of Science Education, v. 5, n. 1, p. 91-101, 2009.

SANDERS, M.; NGXOLA, N. Addressing teachers' concerns about teaching evolution. Journal of Biological Education, v. 43, n. 3, p. 121-128, 2009.

SANTOS, S. Evolução biológica: ensino e aprendizagem no cotidiano de sala de aula. São Paulo: Annablume, 2002. 
SBPC. Ofício 122 Contrário ao PL 8099/2014, Disponível em http://www.sbpcnet.org.br/site/artigos-e-manifestos/detalhe.php?p=3572. Acesso em 09/04/2015.

SCOTT, E. Evolution vs. creationism: an introduction. 2nd. Berkeley: University of California Press, 2009.

SEEDUC. Currículo Mínimo 2012: Ciências e Biologia. Governo do Estado do Rio de Janeiro, 2012.

SMITH, M. U. Current Status of Research in Teaching and Learning Evolution: I.

Philosophical/Epistemological Issues. Science \& Education, v. 19, n. 6-8, p. 523-538, 2010.

SMITH, M. U.; SIEGEL, H. Knowing, Believing, and Understanding: What Goals for Science Education? Science \& Education, v. 13, n. 6, p. 553-582, 2004.

TUFFANI, M. Projeto criacionista de Feliciano é um monumento à ignorância. Disponível em

http://mauriciotuffani.blogfolha.uol.com.br/2014/11/15/projetocriacionistadefelicianoeum monumentoaignorancia/ Acesso em 19/12/2014.

\section{SOBRE OS AUTORES}

PEDRO TEIXEIRA. É doutor em Ciências Humanas (Educação) pela Pontifícia Universidade Católica do Rio de Janeiro (PUC-Rio), tendo realizado período sanduíche no Institute of Education da University College London (UCL IOE, UK) sob a supervisão do professor Ralph Levinson. É mestre em Educação pela PUC-Rio e licenciado em Ciências Biológicas pela Universidade Federal do Rio de Janeiro (UFRJ). Desenvolve pesquisas em Educação e Ensino de Biologia, com foco em evolução, criacionismo, ciência, religião, diversidade e interculturalidade em contextos escolares. É professor do Curso de Especialização Saberes e Práticas na Educação Básica (CESPEB-UFRJ). Atua na educação básica como professor de Biologia e Ciências no Ensino Fundamental e Ensino Médio do Colégio de Aplicação da UFRJ e na rede particular.

RALPH LEVINSON. É bacharel em Biological Chemistry and Zoology (University of Hull), PGCE (Biology, King's College) possui mestrado em Education (Open University) e $\mathrm{PhD}$ em Education (University of London), University of London é professor de Educação no Instituto de Educação da Universidade de Londres. É diretor e professor do programa de Mestrado em Educação em Ciências e orientador de teses de doutorado. Atua, ainda, como professor nos programas de formação inicial e continuada de professores. Seus principais interesses de pesquisa são questões sócio-científicas e alfabetização científica, ciência e justiça social, educação científica e criatividade, educação em química e pedagogia em ciências. Coordena projetos de pesquisa para organizações como o Banco Mundial, o Wellcome Trust, a British Academy e faz parte de dois projetos da União Europeia, além de parcerias com pesquisadores em diversos outros países, incluindo o Brasil.

Recebido: 11 de março de 2017.

Revisado: 22 de agosto de 2017.

Aceito: 14 de setembro de 2017. 